九州大学学術情報リポジトリ

Kyushu University Institutional Repository

\title{
DESCRIPTIONS OF NEW SPECIES OF GONATOCERUS NEES AND ANAGRUS HALIDAY FROM JAPAN (HYMENOPTERA, MYMARIDAE)
}

Sahad, Kazi Abdus

https://doi.org/10.5109/2430

出版情報: ESAKIA. 19，pp.191-204，1982-11-25. Entomological Laboratory，Faculty of Agriculture, Kyushu University

バージョン :

権利関係 : 


\title{
DESCRIPTIONS OF NEW SPECIES OF GONATOCERUS NEES AND ANAGRUS HALIDAY FROM JAPAN (HYMENOPTERA, MYMARIDAE) ${ }^{1)}$
}

\author{
K azi Abdus Sahad ${ }^{2)}$ \\ Entomological Laboratory, Faculty of Agriculture, \\ Kyushu University, Fukuoka 812, Japan
}

\begin{abstract}
Four new species of the parasitic wasp family Mymaridae, Gonatocerus cincticipitis, Gonatocerus miurai, Anagrus hirashimai and Anagrus japonicus, are described from Japan, and illustrated.
\end{abstract}

Until now no comprehensive taxonomic work was done on the Japanese Gonatocerus and Anagrus although there is a good prospect for exploration and utilization of such useful natural enemies for controlling insect pests of important crops. Thus a taxonomic study of such parasites is a long felt demand. I have undertaken a programme to study Gonatocerus and Anagrus of Japan and adjacent regions. The present paper is a part of this programme, adding four new species to the parasitic wasp fauna of Japan.

Gonatocerus cincticipitis sp. nov. and Gonatocerus miurai sp. nov. were treated as Gonatocerus sp. y and $\mathrm{r}$ respectively in my previous paper (Sahad, 1982) ${ }^{3)}$. Biology of Gonatoceruscincticipitis sp. nov. was studied and discussed in the said paper and it was found to be an important egg parasitoid of the rice green leafhopper, Nephotettix cincticeps Uhler which is a serious pest of rice in many Asian countries.

All the type specimens of four new species are deposited in the Museum of Entomological Laboratory, Faculty of Agriculture, Kyushu University, Fukuoka.

1) Contribution from the Entomological Laboratory, Faculty of Agriculture, Kyushu University, Fukuoka (Ser. 3, No. 123).

2) Permanent Address: Directorate of Agriculture (E \& M), Ministry of Agriculture, 14/2, Topkhana Road, Dacca-2, Bangladesh.

3) Sahad, K. A. (1982) Biology and morphology of Gonatocerus sp. (Hymenoptera, Mymaridae), an egg parasitoid of the green rice leafhopper, Nephotettix cincticeps Uhler (Homoptera, Deltocephalidae). I. Biology. Konty $\hat{u}$, Tokyo, 50 (2) : 246-260. 


\section{Gonatocerus cincticipitis sp. nov.}

Female (Fig. 1 A). Body dark brown with mesoscutum and parapsides darker anteriorly; antennae greyish brown except scapes and pedicels which are yellowish; eyes and ocelli pinkish red; mandibles reddish brown ; wings dusky; legs pale yellow; 6 dark brown bands across dorsum of gaster, basal part being lighter.

Head in front view triangular, in dorsal view rectangular and twice as wide as long; face broad ; eyes large ; ocelli in an obtuse triangle, POL slightly shorter than OOL; antennae slightly shorter than body; radicula elongated, cylindrical, about half as long as scape; scape twice as long as pedicel and flattened on the inner side ; pedicel obconical, twice as long as broad; 1st, 2nd and 3rd funicular segments narrower than following segments, 1st dilated in apical half, twice as long as broad; 2 nd subequal to 3rd and longest of funicular segments, slightly curved ventrally; 3rd dilated apically; 4th to 8th stout and subspherical; 4th shorter than 5th; 6th shortest of all antennal segments; 5th, 7th and 8th subequal in length and each with a pair of crest sen. soria (Fig. 1B); club with 6 sensoria, slightly more than four times as long as broad and as long as 4 preceding segments combined.

Thorax shorter than gaster, pronotum narrow and almost vertical; parapsidal suture distinct, parapsides well apart from each other; scutellum large, transversely ovate (Fig. 1 C) ; metanotum transverse, metapostnotum transversely obovate and smooth; postphragma projecting into the base of propodeum. Fore wing large, apex regularly round (Fig. 1 D) ; marginal vein narrow; stigmal vein one-fourth as long as marginal vein and with 4 sensilla at apex; proximal sensillum below distal macrochaeta (Fig. 1 E) ; discal hairs arise from little beyond the base of marginal vein and cover entire disc of fore wing; longest marginal cilia nearly one-half as long as greatest width of fore wing. Hind wing very narrow, nearly one-eight as broad as fore wing, discal hairs absent except with a pair of short hairs along the anterior and posterior margins ; longest marginal cilia about as long as those of fore wing. Femora robust ; tibiae slender; fore tarsus longer than both femur and tibia; mid and hind tarsi longer than respective femur but shorter than respective tibia; fore tibial spur nearly three-fourths as long as metatarsus.

Gaster conical ; ovipositor slightly exserted ; anal plate bluntly conical with 5 long bristles, 1 in the middle of anterior half and 4 in a transverse row in the posterior half (Fig. $1 \mathrm{~F}$ ).

Male (Fig. 2 A). Similar to female except for the following. Antennae longer than body; radicula almost equal to pedicel in length ; scape as long as 1st funicular segment; 1st slightly shorter than 2nd segment; 2nd to 10th subequal in length and breadth; each funicular segment with 4 crest sensoria (Fig. 2B) ; club narrowly ovate, as long as the preceding segment with 4 sen- 


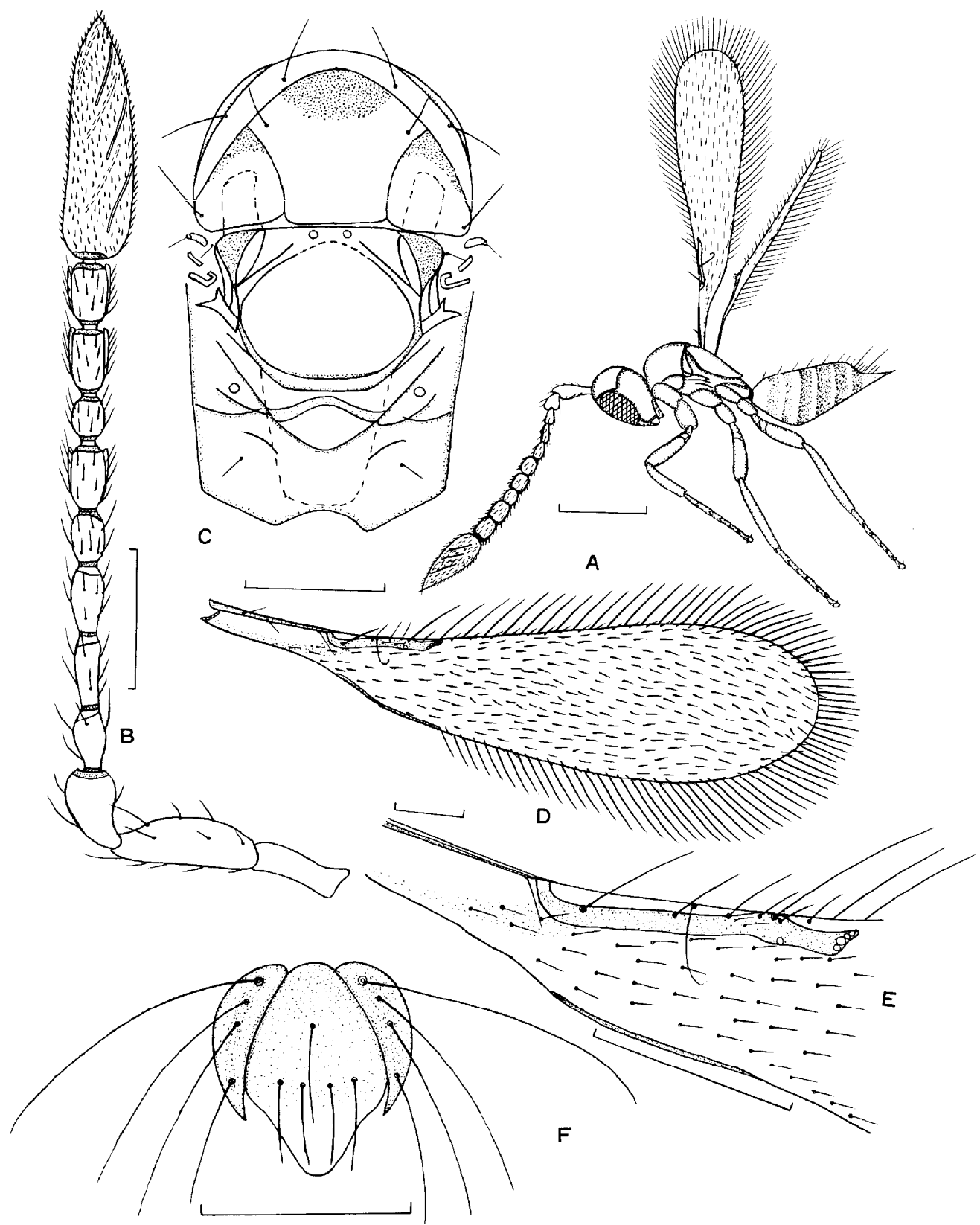

Fig. 1. Gonatocerus cincticipitis sp. nov. A. Female, B. Female antenna, C. Thorax, D. Fore wing, E. Venation, F. Pygostyles and anal plate. Scale for A: $0.25 \mathrm{~mm}$ and B, C, D, E and $F: 0.1 \mathrm{~mm}$. 


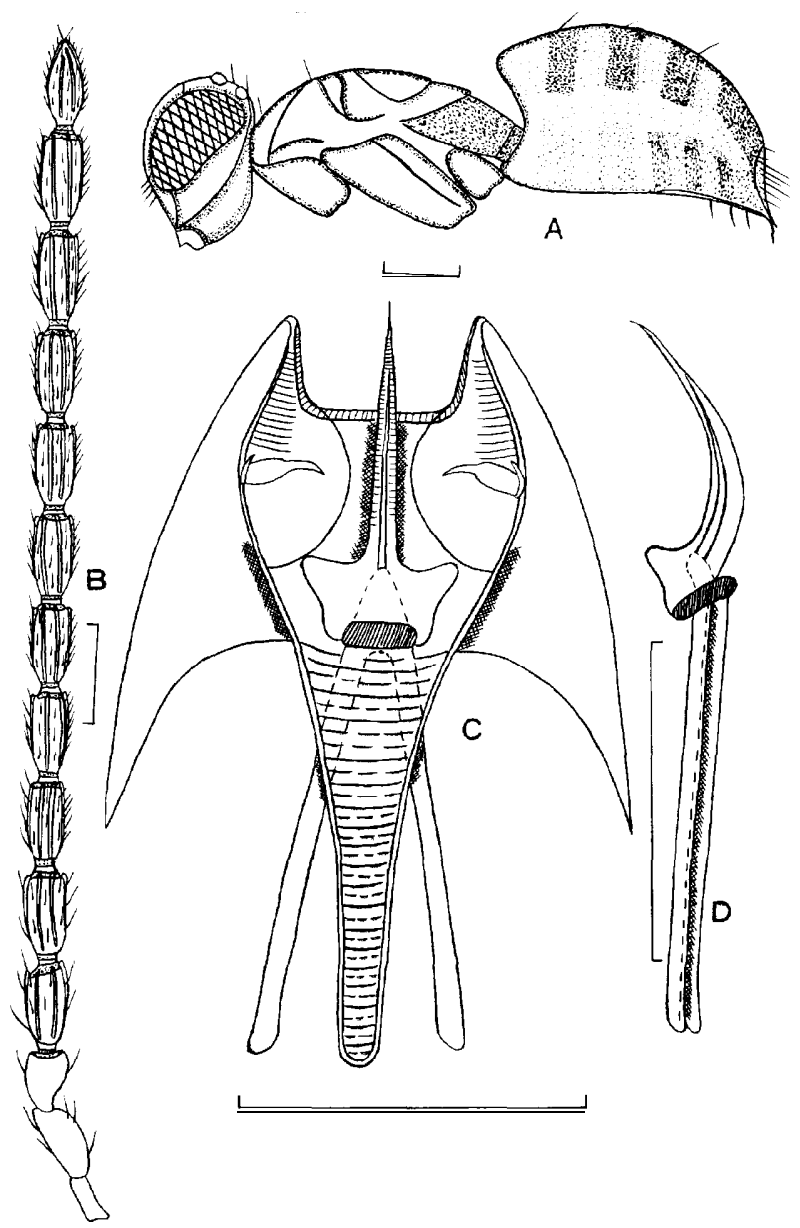

Fig. 2. Gonatocerus cincticipitis sp. nov. A. Male, B. Male antenna, C. Male genitalia (Ventral view), D. Aedeagus (Lateral view). Scale is $0.1 \mathrm{~mm}$ for all.

soria. Gaster subconical, shorter than thorax. Genital apparatus slightly exserted ; digitus volsellaris prominent and provided with a spine at the apex ; cuspis volsellaris present but very small (Fig. 2C); aedeagus cylindrical, long, ventrally curved and sharply pointed at the apex (Fig. 2 D).

Measurement (in $\mathrm{mm}$ ) :

우. Body: 0.835; Head : 0.140 ; Thorax : 0.330 ; Gaster : 0.365 ; Ovipositor : 0.350 .

Antenna. Radicuia : 0.060 ; Scape : 0.110; Pedicel : $0.059 ; \mathrm{F}_{1}: 0.046 ; \mathrm{F}_{2}$ : $0.050 ; \mathrm{F},: 0.050 ; \mathrm{F},: 0.039 ; \mathrm{F},: 0.046 ; \mathrm{F},: 0.036 ; \mathrm{F},: 0.049 ; \mathrm{F},: 0.047$; Club: 0.170 .

Fore wing : $0.950 \times 0.225$; Marginal vein : 0.163 ; Longest marginal cilia : 0.105. 
Hind wing: $0.725 \times 0.025$; Longest marginal cilia : 0.106 .

$\begin{array}{rrcccc}\text { Legs : } & & \text { Coxa } & \text { Femur } & \text { Tibia } & \text { Tarsus } \\ & \text { I. } & 0.110 & 0.210 & 0.181 & 0.235 \\ \text { II. } & 0.074 & 0.224 & 0.266 & 0.248 \\ \text { III. } & 0.111 & 0.238 & 0.293 & 0.275\end{array}$

ð. Body : 0.835 ; Head : 0.140; Thorax : 0.375 ; Gaster : 0.320.

Antenna : Radicula : 0.054; Scape : 0.084; Pedicel : $0.055 ; \mathrm{F}_{1}: 0.085 ; \mathrm{F}_{2}$ : $0.088 ; \mathrm{F},: 0.093 ; \mathrm{F},: 0.093 ; \mathrm{F},: 0.095 ; \mathrm{F},: 0.095 ; \mathrm{F}_{7}: 0.095 ; \mathrm{F},: 0.093 ; \mathrm{F}$, $0.095 ; \mathrm{F}_{10}: 0.093$; Club: 0.093 .

Fore wing : $0.975 \times 0.235$; Marginal vein : 0.160 ; Longest marginal cilia : 0.117.

Hind wing : $0.785 \times 0.025$; Longest marginal cilia : 0.117 .

$\begin{array}{rrcccc}\text { Legs : } & & \text { Coxa } & \text { Femur } & \text { Tibia } & \text { Tarsus } \\ & \text { I. } & 0.115 & 0.250 & 0.215 & 0.263 \\ \text { II. } & 0.085 & 0.235 & 0.300 & 0.270 \\ \text { III. } & 0.120 & 0.260 & 0.320 & 0.295\end{array}$

Host : Rice green leafhopper, Nephotettix cincticeps Uhler.

Distribution: Honshu and Kyushu regions of Japan.

Type materials : Holotype female (Type No. 2385, Kyushu Univ.), Matsue, Shimane Pref., 15. viii. 1978, K. A. Sahad leg. (on slide). Para-

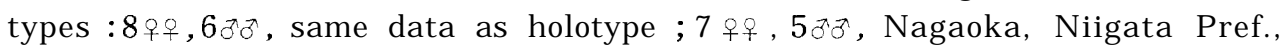
19. viii. 1980, K. A. Sahad leg.; 9 우우,7 7 , Harumachi, Fukuoka, 1. ix. 1979, K. A. Sahad leg. (on slides).

REMARKs : This species resembles Gomatocerus pahlgamensis (Narayanan) known from Kashmir, India, in many respects but differs from it in the length of funicular segments. In Gonatocerus pahlgamensis 6th funicular segment is the longest of funicle whereas in Gonatocerus cincticipitis it is the smallest.

\section{Gonatocerus miurai sp. nov.}

Female. Head, anterior part of mesoscutum, parapsides, scutellum and axilla dark brown; antennae except scapes and pedicels infuscated, scapes and pedicels light brown ; eyes blackish pink; ocelli pink; wings dusky; legs yellowish; gaster with 4 interrupted bands of brown patches. General color of the body as a whole lighter than Gonatocerus cincticipitis sp. nov.

Head two times as wide as long, vertex rectangular; eyes large and elevated upward; ocelli form an obtuse triangle near the middle of occipital carina, POL subequal to OOL; radicula elongated, as long as 2 nd funicular segment; scape slightly less than two times as long as pedicel, about as broad as the latter; 1st funicular segment shorter than 2nd but slightly wider than the latter and subequal to $3 \mathrm{rd} ; 4 \mathrm{th}, 5$ th and 6 th equal in length and breadth and subspherical; 7th and 8th subequal in length and breadth and widest of funicular segments, each with a pair of crest sensoria (Fig. 3 A) ; club with 
6 sensoria and as long as 4 preceding segments combined.

Thorax (Fig. 3B) shorter than gaster; pronotum narrow; parapsidal suture distinct; scutellum large and transversely ovate, metanotum transverse, metapostnotum transversely obovate and smooth like Gonatoceruscincticipitis sp. nov. but differ from the latter in having a transverse carina below metapostnotum. Fore wing (Fig. 3C) longer than body, 4.2 times as long as wide ; longest marginal cilia one- half of the greatest width of fore wing; marginal vein narrow (Fig. $3 \mathrm{D}$ ), one-tenth as wide as long, distal macrochaeta one-half as long as marginal vein; discal hairs originate from the base of marginal vein and cover entire disc of the fore wing, a distinct line of discal hairs arising from the base of marginal vein extends up to hind margin obliquely. Hind wing about one-fifth shorter than fore wing, very narrow; longest marginal cilia equal to those of fore wing; disc free from hairs except one pair of sparse hairs along anterior and posterior margins. Fore and mid femora equal in length, fore and hind coxae subequal in length, hind tibia and tarsus subequal in length, fore tibia shorter than both femur and tarsus but mid and hind tibiae longer than respective femora and tarsi.

Gaster conical (Fig. 3E) ; ovipositor slightly shorter than gaster, not exserted or very slightly exserted; anal plate narrowly conical with 5 long bristles (Fig. $3 \mathrm{~F}$ ).

Male (Fig. 3G). Very similar to female except antennal, genitalic and gastral structures. Scape 2.5 times as long as wide ; pedicel 1.2 times as long as wide; 1st funicular segment shortest of flagellar segments and following segments subequal in length (Fig. $3 \mathrm{H}$ ). Aedeagus cylindrical, sharply pointed at the tip and slightly exserted like that of Gonatoceruscincticipitis sp. nov. Gaster shorter than thorax, highly convex compared to preceding species and blunt at the posterior end.

Measurement (in $\mathrm{mm})$ :

ㅇ. Body : 0.835; Head : 0.130; Thorax : 0.325 ; Gaster : 0.380 ; Ovipositor : 0.375 .

Antenna. Radicula : 0.050 ; Scape : 0.113 ; Pedicel : $0.063 ; F_{1}: 0.044 ; F_{2}$ : $0.050 ; \mathrm{F},: 0.050 ; \mathrm{F},: 0.038 ; \mathrm{F},: 0.038 ; \mathrm{F}_{6}: 0.038 ; \mathrm{F},: 0.053 ; \mathrm{F},: 0.050 ;$ Club: 0.175 .

Fore wing : $0.950 \times 0.225$; Marginal vein : 0.150 ; Longest marginal cilia : 0.100.

Hind wing: $0.750 \times 0.025$; Longest marginal cilia : 0.100 .

\begin{tabular}{|c|c|c|c|c|}
\hline Legs : & Coxa & Femur & Tibia & Tarsus \\
\hline I. & 0.112 & 0.225 & 0.188 & 0.250 \\
\hline II. & 0.072 & 0.225 & 0.275 & 0.263 \\
\hline III. & 0.112 & 0.243 & 0.290 & 0.288 \\
\hline
\end{tabular}

ॐ. Body : 0.800 ; Head : 0.130; Thorax : 0.340 ; Gaster : 0.330.

Antenna. Radicula : 0.045 ; Scape : 0.078; Pedicel: $0.045 ; F_{1}: 0.055 ; F_{2}$ : 


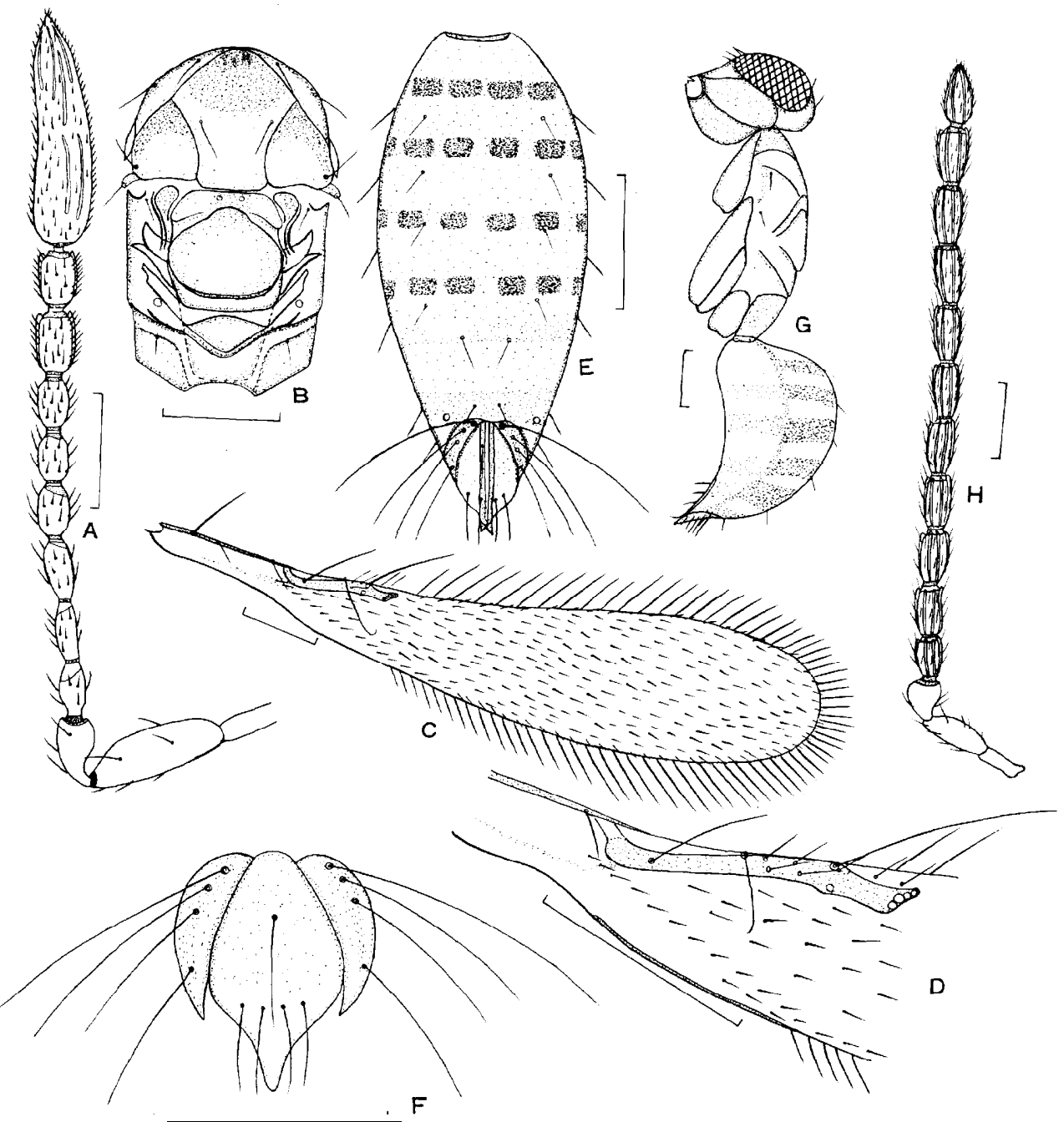

Fig. 3. Gonatocerus miurai sp. nov. A. Female, antenna, B. Thorax, C. Fore wing, D. Venation, E. Female gaster, F. Anal plate, G. Male, H. Male antenna. Scale: $0.1 \mathrm{~mm}$ for all.

$0.068 ; \mathrm{F},: 0.068 ; \mathrm{F}_{4}: 0.068 ; \mathrm{F}_{5}: 0.070 ; \mathrm{F}_{1}: 0.068 ; \mathrm{F}_{7}: 0.068 ; \mathrm{F}_{8}: 0.068 ; \mathrm{F},:$ $0.070 ; \mathrm{F}_{10}: 0.072 ; \mathrm{Club}: 0.072$.

Fore wing: $0.950 \times 0.200$; Marginal vein: 0.160 ; Longest marginal cilia: 0.115 .

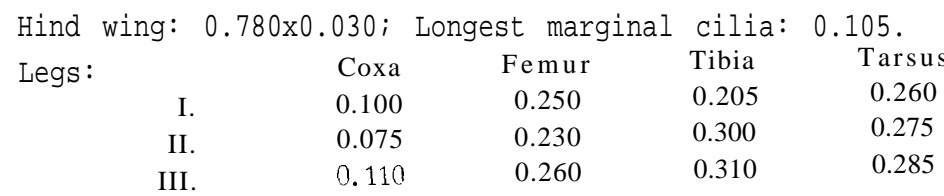

Host: Rice green leafhopper, Nephotettix cincticeps Uhler. 
Distribution: Honshu and Kyushu regions of Japan.

Type materials : Holotype female (Type No. 2386, Kyushu Univ.), Matsue, Shimane Pref., 20. viii. 1978, K. A. Sahad leg. (on slide). Paratypes :5 우우,

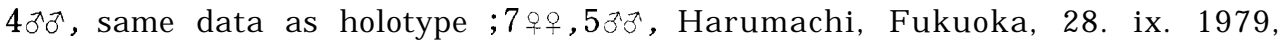
K. A. Sahad leg. (on slides).

REMARKS: This species is a close ally of Gonatocerus cincticipitis sp. nov. but it can be easily differentiated from the latter by origination of discal hairs and structure of funicular segments. In Gonatocerus cincticipitis discal hairs originate from a little beyond the base of marginal vein, 6th funicular segment is the smallest and 5th, 7th and 8th with crest sensoria whereas in Gonatocerus miuraidiscal hairs arise from the base of the marginal vein and form a distinct oblique line to the hind margin, 6th funicular segment is subequal to 4 th and 5 th, and only 7 th and 8 th with crest sensoria.

This species is named in honour of Prof. T. Miura of Shimane University, who rendered invaluable cooperation and guidance during field study of these parasitoids.

\section{Key to the Japanese SPecies (Females) of Gonatocerus NeES}

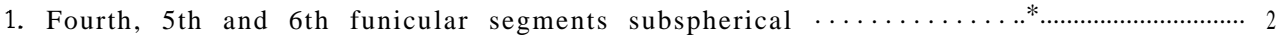

- Fifth, 6th and 7th funicular segments subcylindrical .................................. 4

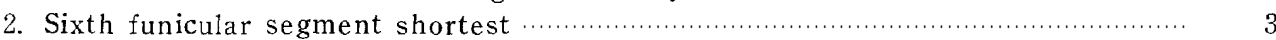

- Sixth funicular segment equal to 4th, which is equal to 5th; 7 th and 8 th each with a pair of crest sensoria; discal hairs originate from base of marginal vein and form a distinct oblique line to hind margin of fore wing; gaster with four interrupted bands of brown patches; anal plate narrowly conical

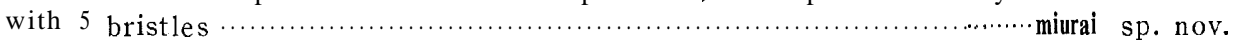

3. Fifth, 7 th and 8 th funicular segments with a pair of crest sensoria, discal hairs originate from a little beyond base of marginal vein; anal plate broadly

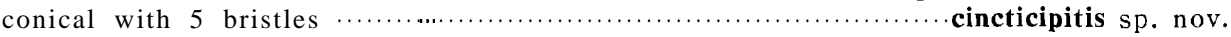

- Seventh and 8th funicular segments with a pair of crest sensoria; a convex carina in between basal part of parapsidal sutures forms a semicircular space with scutoscutellar suture ; anal plate ampulliform with 4 bristles

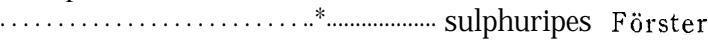

4. First to 4th funicular segments appreciably shorter than following segments; 5 th, 7 th and 8 th each with a pair of crest sensoria; 8th with a cavity; proximal sensillum lies in the middle of distal macrochaeta and distal sensilla on stigma1 vein; anal plate bluntly conical with 4 bristles .............. litoralis (Haliday)

- Second to 8th funicular segments almost cylindrical and subequal; 5th to 8th each with a pair of crest sensoria; p roximal sensillum lies below the distal macrochaeta; anal plate oval-shaped with 5 bristles cicadellae Nikolskaya

Anagrus hirashimai sp. nov.

Female (Fig. 4 A). Head and basal five tergites of gaster blackish brown; antennae pale greyish except scapes and pedicels which are pale yellowish but dorsal surfaces of scapes concolorous with funicle; eyes and ocelli pinkish 


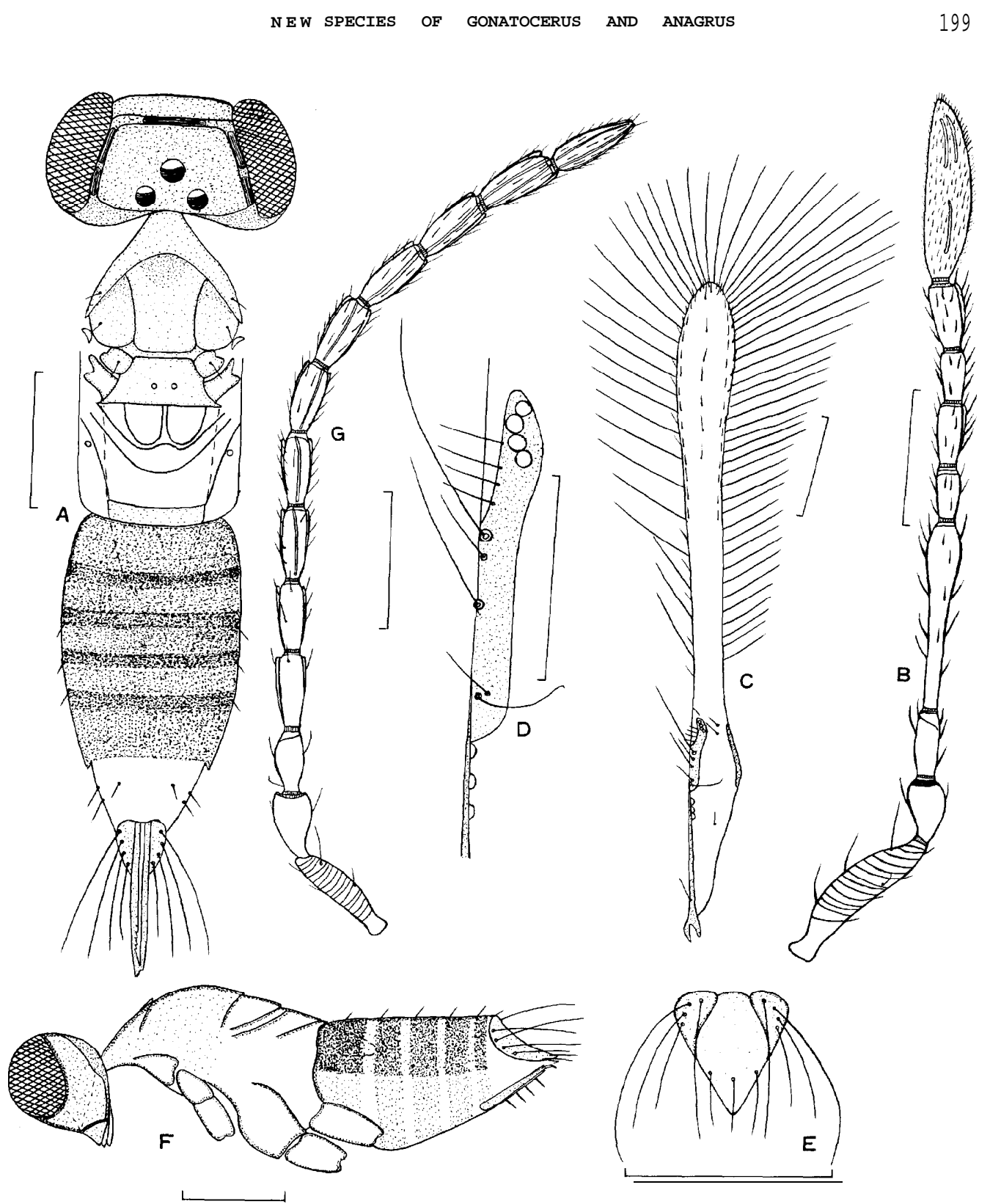

Fig. 4. Anagrus hirashimai sp. nov. A. Female, B. Female antenna, C. Fore wing, D. Venation, E. Pygostyles and anal plate, F. Male, G. Male antenna. Scale, for A, B, C, E, F and $\mathrm{G}: 0.1 \mathrm{~mm}$, and $\mathrm{D}: 0.05 \mathrm{~mm}$.

red; pronotum and mesonotum infuscated ; metanotum and propodeum light yellow; wings dusky; marginal vein and its surrounding pale brown ; legs Iuteous ; ovipositor reddish brown.

Head a little broader than thorax, about two times as wide as long; vertex 
rectangular; face triangular ; eyes large, reniform; ocelli form an obtuse triangle adjacent to the middle part of occipital carina; OOL about two times as long as POL. Antennae with base widely separated, close to eyes; scape with 13 transverse lines, slightly more than twice as long as pedicel; pedicel pear-shaped, twice as long as wide; 1st funicular segment slightly longer than 3rd; 2nd exceptionally long (Fig. 4B), more than three times as long as 1st and slightly longer than club, posterior half slender and cylindrical, anterior part gradually slightly dilated; 3rd and 5th subequal in length and breadth; 4 th as long as 6th; the latter not only wider than former but also widest of funicle segments ; 4 th and 6th each with a crest sensorium; club about three times as long as preceding segment.

Thorax about two times as long as head; parapsidal furrows complete and widely apart; mesonotum longer than broad; scutellum as long as broad. Fore wing moderately slender, gradually slightly dilated and curved at apical $1 / 3$, nearly twelve times as long as wide; disc almost bare except a single line of 7 to 10 hairs at the center of distal $1 / 4$ of the wing and at anterior and posterior margins one pair of short hairs arising from a little beyond proximal end of central line run up to the apex (Fig. 4C) ; longest marginal cilia three and half times as long as greatest width of fore wing; marginal vein (Fig. 4 D) eight times as long as wide, distal macrochaeta very long, about twice as long as proximal macrochaeta, hypochaeta curved; four sensilla form a crescent shape at the apex of stigma. Hind wing very narrow, longest marginal cilia six times as long as greatest width of hind wing, disc free from hairs except one line of short hairs along posterior margin and only 3 or 4 hairs along anterior margin at apical part; fore and mid tarsi. and mid tibia equal in length, fore and hind femora subequal in length.

Gaster longer than thorax, conical, broadly sessile, postphragma projected up to 2nd tergite of gaster ; ovipositor issuing near its base and protruded up to $1 / 4$ of the length of gaster; anal plate with 3 bristles (Fig. 4 E).

Male (Fig. 4F). Similar to female except for the following. Scape about two times as long as pedicel; pedicel equal to 1st funicular segment but shorter than 2nd which is slightly longer than 3rd; 3rd to 10th subequal; 1st with 2 crest sensoria ; 2nd to 10th each with 3 to 4 sensoria; club with 4 crest sensoria, as long as preceding segment (Fig. 4 G). Gaster subconical and subequal to thorax; aedeagus stout, conical and ventrally curved.

Measurement (in $\mathrm{mm}$ ) :

؟. Body: 0.600 ; Head : 0.100; Thorax : 0.200 ; Gaster : 0.300; Ovipositor: 0.325 .

Antenna. Scape : 0.120 ; Pedicel : $0.050 ; \mathrm{F},: 0.043 ; \mathrm{F}_{2}: 0.150 ; \mathrm{F}_{3}: 0.038$; $\mathrm{F},: 0.045 ; \mathrm{F}, \mathrm{:} 0.038 ; \mathrm{F}_{6}: 0.045 ;$ Club: 0.133 .

Fore wing : $0.625 \times 0.055$; Marginal vein : 0.088 ; Longest marginal cilia : 0. 195 . 
Hind wing: $0.590 \times 0.024$; Longest marginal cilia : 0.145 .

Legs:

$\begin{array}{rrrrrr} & \text { Coxa } & \text { Femur } & & \text { Tibia } & \text { Tarsus } \\ \text { I. } & 0.075 & 0.180 & 0 . & 135 & 0.200 \\ \text { II. } & 0.050 & 0.128 & 0 . & 200 & 0.200 \\ \text { III. } & 0.093 & 0.183 & & 0.230 & 0.213\end{array}$

ॐ. Body : 0.525; Head : 0.065 ; Thorax : 0.225 ; Gaster : 0.235 .

Antenna Scape : 0.088; Pedicel : $0.045 ; \mathrm{F}_{1}: 0.045 ; \mathrm{F}_{2}: 0.058 ; \mathrm{F}_{3}: 0.053$; $\mathrm{F},: 0.053 ; \mathrm{F},: 0.050 ; \mathrm{F},: 0.050 ; \mathrm{F},: 0.050 ; \mathrm{F},: 0.053 ; \mathrm{F},: 0.055 ; \mathrm{F}_{10}: 0.053$; Club : 0.053 .

Fore wing : $0.590 \times 0.050$; Marginal vein : 0.078 ; Longest marginal cilia : 0.192 .

Hind wing : $0.550 \times 0.022$; Longest marginal cilia : 0.140 .

\begin{tabular}{|c|c|c|c|c|}
\hline Legs: & Coxa & Femur & Tibia & Tarsus \\
\hline I. & 0.070 & 0.170 & 0. 133 & 0.198 \\
\hline II. & 0.055 & 0.163 & 0.175 & 0.183 \\
\hline III. & 0.080 & 0.165 & 0. 205 & 0.205 \\
\hline
\end{tabular}

Host: Unknown. Captured in the Imperatacylindrica (L.) field by suction trap.

Distribution: Kyushu region of Japan.

Type materials : Holotype female (Type No. 2387, Kyushu Univ.), Hakozaki, Fukuoka Pref ., 10. viii. 1981, K. A. Sahad leg. (on slide). Paratopotypes : 2 우, 1 đ, 29. viii. 1981, K. A. Sahad leg. ; 5우우,1ð, 9. vi. 1982, same collector as above ;6우,1\%, 18. vi. 1982, same collector as above (on slides).

REMARKS: This species has similarity to Anagms funebris Mathot from Congo but it differs from the latter in respect of proportional length of antennal segments and ovipositor. In Anagms funebris 2nd funicular segment is slightly more than two times as long as lst, club longer than 2nd and ovipositor exceptionally long for this genus, more than two times as long as gaster whereas in Anagms hirashimai 2nd funicular segment is more than three times as long as lst, club shorter than 2nd and ovipositor slightly longer than gaster and moderately exserted.

This species is named in honour of Prof. Y. Hirashima of Kyushu University for his dedication and contribution to the study of hymenopterous insects.

\section{Anagrus japonicus sp. nov.}

Female (Fig. 5 A). In alive general color yellowish grey but after death in alcohol color faded and turned to infuscous; vertex, notum and tergum smoky grey brown; funicle pale brown ; scapes and clubs greyish ; eyes blackish red; wings dusky; coxae and femora yellowish ; tibiae and tarsiconcolor. ous with funicle.

Head one and half times as wide as long; eyes large and elevated up- 
ward; OOL one and half times as long as POL; POL equal to the width of a posterior ocellus; antenna as a whole stout; scape with 12 or 13 transverse lines, about two times as long as pedicel; pedicel two times as long as 1st funicular segment; 1st segment globular, slightly longer than breadth; 2nd slightly longer than 3rd ; 4th to 6th gradually very slightly increased in length and breadth and each with a pair of crest sensoria (Fig. 5B); club about two times as long as preceding segment, with 4 sensoria.

Thorax (Fig. 5C) slightly less than two times as long as head but equal in width ; parapsidal furrows complete and widely apart ; postphragma broad and projected up to 3rd tergite of gaster. Fore wing slightly longer than body, slightly expanded and curved at distal $1 / 3$; one median longitudinal line of discal hairs starting little away from tip of marginal vein extends up to apex of wing (Fig. $5 \mathrm{D}$ ), between this central line and anterior margin another line of hairs arising from the middle of wing runs along it, at the middle between central line and posterior margin 4 or 5 hairs form a small line connecting marginal hairs ; marginal vein (Fig. 5E) as long as distal macrochaeta ; stigma with 4 sensillae. Hind wing (Fig. $5 \mathrm{~F}$ ) almost equal to length of body, very narrow, about $1 / 22$ as wide as long; disc free from hairs except one single line of short hairs along anterior and posterior margins, the former being too sparse. Fore and mid femora and mid tibia equal in length; fore, mid and hind tarsi subequal.

Gaster equal to thorax, conical, broadly sessile ; ovipositor originated from little beyond base of gaster and protruded up to a length of $1 / 4.5$ of gaster.

Measurement (in $\mathrm{mm}$ ) :

Body: 0.350; Head : 0.075 ; Thorax : 0.137 : Gaster : 0.138 ; Ovipositor : 0.205.

Antenna. Scape : 0.063; Pedicel: 0.033; F,: 0.015; $\mathrm{F}_{2}: 0.027 ; \mathrm{F},: 0.021$; $\mathrm{F}_{4}: 0.040 ; \mathrm{F}_{5}: 0.043 ; \mathrm{F}_{6}: 0.046 ;$ Club : 0.088

Fore wing: $0.375 \times 0.050$; Marginal vein : 0.060 ; Longest marginal cilia : 0.188 .

Hind wing : $0.350 \times 0.016$; Longest marginal cilia : 0.150 .

$\begin{array}{rrcccc}\text { Legs: } & & \text { Coxa } & \text { Femur } & \text { Tibia } & \text { Tarsus } \\ & \text { I. } & 0.045 & 0.120 & 0.090 & 0.133 \\ & \text { II. } & 0.038 & 0{ }^{\star} 120 & 0.120 & 0.135 \\ \text { III. } & 0.063 & 0.125 & 0.130 & 0.135\end{array}$

Male. Unknown.

Host : Unknown. Captured in the Imperata cylindrica (L.) field by suction trap. Distribution: Kyushu region of Japan.

Type material: Holotype female (Type No. 2388, Kyushu Univ.), Hakozaki, Fukuoka Pref., 23. ix. 1981, K. A. Sahad leg. (on slide).

REMARKS: This species resembles Anagrus epos Girault known from Centralia, Illinois, but it readily differs from the latter in the length of funicular 


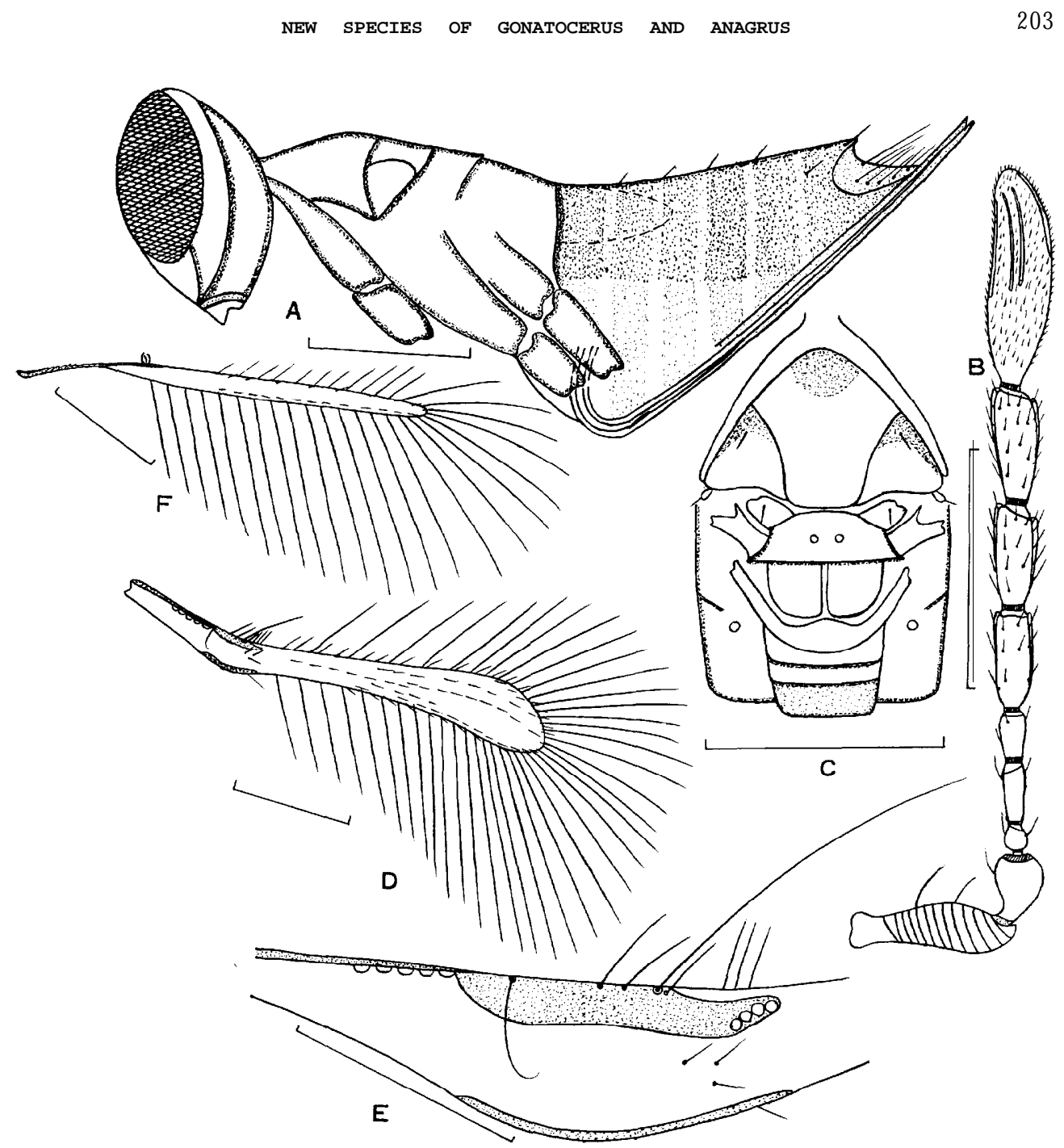

Fig. 5. Anagrus japonicus sp. nov. A. Female, B. Female antenna, C. Thorax, D. Fore wing, E. Venation, F. Hind wing. Scale for A, B, C, D and F : $0.1 \mathrm{~mm}$, and E: $0.05 \mathrm{~mm}$.

segments, distribution of discal hairs and projection of postphragma. In this species the 2nd funicular segment distinctly longer than 3rd, the central line of discal hairs originate from a little beyond the apex of stigma1 vein and postphragma projected up to the 3rd tergite of gaster. In Anagnusepos 2nd funicular segment shorter than 3rd, central line of discal hairs arises from the base of marginal vein and postphragma projected up to 2nd tergite of the gaster.

$$
\text { key to the Japanese species (females) of Anagrus haliday }
$$

1. First funicular segment very short and subspherical or globular …........................ 2

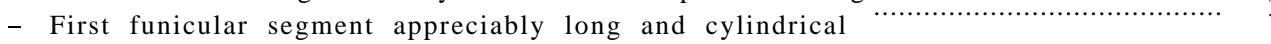


2. Second funicular segment longest of funicle, nearly as long as pedicel and 1 st taken together; fore wing 9.3 times as long as broad; at the broadest part of fore wing there are 3 or 4 rows of discal hairs in between the lines of anterior and posterior marginal hairs ; ovipositor exserted to $1 / 7.5$ of its

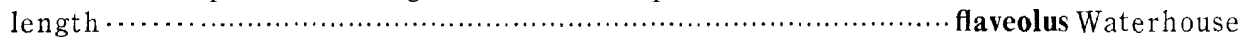

- Second funicular segment longer than 3rd but shorter than following segments ; between the lines of marginal hairs only a pair of discal hairs present at anterior half of fore wing; postphragma projected up to 3rd tergite of

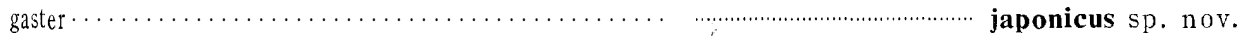

3. First funicular segment distinctly shorter than pedicel but longer than 3rd or 5th; 2nd exceptionally long, longer than club; disc consists of a short midlongitudinal line of 7 to 10 hairs at distal $1 / 4$ of fore wing; gaster up to 5 th

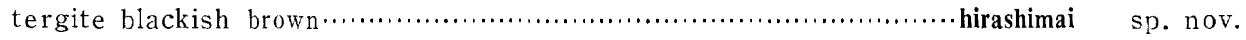

- First funicular segment subequal to pedicel and 2nd subequal to 3 rd, 4th, 5 th and 6th in length; an elongate infuscous subtriangular spot on either side of the middle line of mesoscutum; ovipositor moderately exserted, ratio of gaster and exserted part $6: 1$

optabilis (Perkins)

\section{Acknowledgements}

I am very grateful to Prof. Y. Hirashima of Entomological Laboratory, Kyushu University, for his kind continuous guidance in studying the mymarid parasites of leaf- and planthoppers. I also remember with gratitude the sincere cooperations of the following devoted entomologists who have kindly lent me valuable type materials in connection with my study: Dr. A. Menke and Dr. E. E. Grissell, Systematic Entomology Laboratory, USDA, Washington; Mr. Gordon Nishida, Bishop Museum, Hawaii ; Dr. Max Fisher, Museum of Natural History, Vienna, Austria ; and Dr. Wallace E. LaBerge, Section of Faunistic Survey and Insect Identification, Illinois. I am also indebted to Mr. Carl M. Yoshimoto, Biosystematics Research Institute, Canada, Dr. D. P. Annecke, Plant Protection Research Institute, Republic of South Africa; Prof. M. S. Mani, St. John's College, Agra, India, and Mr. H. Taguchi, Kaida High School, Hiroshima, Japan, for their kind advice and supply of literatures. I am thankful to Assoc. Prof. K. Morimoto, Assoc. Prof. M. T. Chûjô and Dr. 0. Tadauchi of Kyushu University for encouragement and various cooperations for this study. 